\title{
GOING AGAINST THE TIDE: SEEKING REGULATIONS FOR PRIVATE MILITARY/SECURITY COMPANIES IN A GLOBALIZED WORLD
}

Laurence Juma

LLB LLM MA LLD

Associate Professor, Faculty of Law

Rhodes University

SUMMARY

This article discusses the role of privatization of security in Africa, but its focus is on private military and security companies (PMSCs). The article proceeds on the basis that there is need for effective regulatory frameworks for PMSCs that operate in conflict zones of Africa. Thus, it begins by appraising the existing normative standards at the international, regional and domestic level that apply to these companies, and thereafter, identifies their shortcomings in light of the prevailing security conditions within the continent. The article then posits broad theoretical imperatives for designing a more effective regulatory framework for PMSCs and concludes by proposing the establishment an overarching continental regime constructed on the basis of the suggested imperatives.

\section{$1 \quad$ INTRODUCTION}

Privatization of security is a phenomenon that is attracting considerable attention from scholars across disciplines. ${ }^{1}$ This is hardly surprising in view of the rapid expansion of the industry in the last two decades or so. One study estimated that the industry might control up to $\$ 202$ billion in revenue by the end of 2010, a figure that was relatively conservative considering the widespread use of private security in many parts of the world. ${ }^{2}$ But despite the exponential growth, the phenomenon still draws mixed reaction from scholars in the developing world, and especially in Africa. While some applaud privatization as providing a suitable alternative to traditionally weak, overburdened and corrupt bureaucracies, others lament the erosion of the coercive power of the state and its diminished ability to assert sovereignty. Nonetheless, the debate goes beyond this dissonance of views to elicit a

Krahmann "Security: Collective Good or Commodity" 2008 14(3) European Journal of international Relations 379; Cottier "Elements for Contracting and Regulating Private Security and Military Companies" 2006 88(863) International Review of the Red Cross 637-663; Avant The Market for Force: The Consequences of Privatising Security (2005); and Singer Corporate Warriors: The Rise of the Privatized Military Industry (2003) 101.

2 Leander "The Power to Construct International Security: On Significance of Private Military Companies" 2005 33(3) Millennium-Journal of International Studies 803806. 
much wider appraisal of the role of private security in Africa's quest for peace and economic revival. But pragmatism and Africa's inability to extricate itself from the global economy have consigned the debate to the narrow ends of academia. Moreover, this dichotomy of opinion collapses on a relatively short term when a broad consensus is struck on the legitimacy of such entities, and issues of human rights and observance of principles of humanitarian law gain ascendancy in the security discourse. What we see today is a general shift from attention to moral standing of private security industry to the exploration of strategies for improving its relationship with states. In this regard, the suspect performance of some entities now affirms the ubiquitous need for an effective regulatory framework, rather than need for the proscription of the entire industry.

The argument that transgressions by the private security operatives could be addressed by stricter normative regime is hardly contested even as the industry gains more legitimacy in the realm of international law. The question, though, is: What kind of regulatory frameworks should there be, and which institutions should have custody of it? These questions have become poignant because there seems to be some reluctance in the international fora to create stricter standards, in the form of binding treaties, for the regulations of private security firms operating in conflict situations. So far, efforts to regulate private military/security companies ${ }^{3}$ have been ad hoc, mainly geared towards erasing the label of the "mercenary" and sanitizing the image of industry, rather than addressing the broader security needs of the majority of countries in the south. ${ }^{4}$ Much of the talk on PMSCs has centred on how such companies can gain access to the African market, thus emphasizing their sophistication in dealing with threats, rather than harnessing the positive linkages between security and Africa's stability and economic revival.

This article suggests that since globalization and the concomitant neoliberal approaches to security have impacted on Africa rather adversely, regulatory frameworks for the security sector should be part of the whole processes of "recovery" that the continent now aspires. Rather than concern itself with norm formulation, the article will outline broad approaches to PMSCs' regulation that takes on board the particularities of Africa. It will do so by first appraising the existing regulatory frameworks at the domestic and international level and then, drawing on their shortcomings, suggest imperatives sensitive to the African situation that should inform normative efforts in the days to come. This approach is informed by the belief that Africa's recovery lie, not in isolation, but in repositioning itself so as to take advantage of the new trends in the global economy. Thus, it argues that PMSCs should not be discounted on the same terms that mercenaries were, but embraced in a new framework that redirects their utility towards bolstering

\footnotetext{
Hereinafter "PMSCs".

4 The discussions in this article are limited to the private security entities that operate in situations of conflict. These are often referred to as private military/security companies (PMSCs). This characterization is not without controversy. Some operatives have suggested that the label "military" may suggest that the companies are engaged in military activities, which may not be entirely true. In United States, the term "contingency contractors" is preferred to minimize the controversy that the nomenclature often produce. See Brooks "In Search of Adequate Legal and Regulatory Frameworks" 2007 2(5) Journal of International Peace Operations 4.
} 
security in the continent and uplifting conditions of life. Finally the article will suggest that the best way to infuse urgency in individual countries response to the need for law and regulatory mechanisms is to set the minimum standards at the continental level and then cascade the rules down to individual countries.

\section{PRIVATIZATION: TRENDS AND IMPLICATIONS}

\section{Setting the agenda}

The growth of PMSCs can be linked to rise of neo-liberal economic models that promote privatization and so called "outsourcing" of goods and services. These models have blurred the distinction between the "public" and the "private" domains as far trade in goods and services are concerned. As the security industry imbibes these new trends and the state becomes less visible, new rules of the game have emerged. Already, we are witnessing massive fragmentation of security functions within and outside states, and an increasing number of individuals and private companies taking control of their own security. In United Kingdom and United States of America for example, privatization of security has become entrenched in the practice of government. Garland observes that the growth of privatization in security in these countries evinces a shift in governance strategies - where the private security entities are enlisted into what he calls the "rule at a distance". ${ }^{5} \mathrm{He}$ argues that although the state may still be crucial to security governance, its role is more of "steering" rather than "rowing". ${ }^{6}$ Why should these developments raise hue and cry among nations in the south, particularly Africa? Unfortunately, the "steering" role of the African state translates into lesser control over the consequences of globalization and loss of protection for those who are adversely affected. ${ }^{7}$ Moreover, since globalization and its privatization agenda are generally ambivalent to strict oversight, the dangers such as those manifest in PMSCs operations around the world, are all too evident. This in a nutshell, outlines the genesis of what is referred to here as the PMSC problematique!

\section{The PMSC's problematique}

In a majority of literature, the PMSC problematique is presented as the deficiency in regulatory frameworks - the argument being that PMSCs are

\footnotetext{
Garland The Culture of Control: Crime and Social Order in Contemporary Society (2001) 15. Ibid.

The literature on globalization and its consequences are many and cover a wide range of subjects. See Donnelly "Human Rights, Globalizing Flows and State Power" in Brysk (ed) Globalization and Human Rights (2002) 226; Mukherjee "Women and Work in the Shadow of Globalization" 2004 Indian Journal of Gender Studies 275; Contrepois and Jeffreys "Trade Unionism Under Challenge from Offshoring and Globalization" 200511 Transfer: European Review of Labor Research 549; Dobson "Globalization Cosmopolitanism and Environment" 200519 International Relations 259; Harrington "Law Globalization and the NHS" 200731 Capital \& Class 81; and Chandler "The Global Ideology: Rethinking the Politics of the "Global Turn' in IR" 200923 International Relations 530.
} 
different from "mercenaries" and therefore they exist outside the current antimercenary regimes. ${ }^{8}$ Leander summarizes it as follows:

"How to hold firms and their employees accountable, how to keep states accountable, how to ensure that command hierarchies and the responsibilities are clear in the armed forces, and how to create the administrative structures necessary to manage the blurring between private/public line."

This may very well be so, but why has it been impossible to get over this problem for the two decades that PMSCs have been with us? Indeed, this takes us to the political exigency debate. Do the critical political constituencies consider the regulation of PMSCs desirable at this moment? I believe that the answer is no. Despite the ever persistent call to create regimes that will demand accountability for PMSCs and ensure their effective compliance with international normative standards, the response in terms of political goodwill has been dismal. Rules and regulations are often a product of conscious action by those who control political processes. Powerful normative standards such as the Universal Declaration of Human Rights and Agenda 21 of the Rio Declaration on the state of the environment, and products of political processes such as the breakdown of the Berlin wall and the collapse of communism. Currently, the momentum for the regulation of PMSCs has not claimed such a support. Another angle to this argument is that, by and large, those who are pushing the neo-liberal agenda are also the warmongers of this century. A non-regulated PMSC industry may suit the military adventurism that we have seen in Lebanon, Afghanistan, Iraq and Chechnya. It seems as though we are entering a new era in international relations where rules of engagement are kept deliberately fuzzy to mask activities of agencies acting on behalf of states.

In my view, there are three facets to the normative-deficiency debate that call for attention, but which are all inextricably linked to the political question. To begin with, we must recognize that it is because of globalization that PMSCs have become palatable within the international security discourse. Invariably, PMSCs have, to a large extent, shaken off the opprobrious label that linked them to mercenaries and are now seen as a legitimate part of any major security undertaking. Despite the recognizable shift towards acknowledging that the difference between mercenaries and PMSCs, a handful of scholars still view PMSCs that operate in African conflict zones as the newer forms of "mercenaries". ${ }^{10}$ This contestation on the status of PMSCs does reflect a discordance in thinking among neo-liberalists as to the extent to which privatization should go, and may very well be the prime catalyst for the normative deficiency debate. In my view, however, the contestation clouds the debate with uncertainty which is being exploited by those who disfavour stricter regulation for PMSCs. Whether or not PMSCs are newer forms of

8 Cockayne "Regulating Private Military and Security Companies: The Content, Negotiation, Weakness and Promise of the Motreux Document" 2009 13(3) Journal of Conflict \& Security Law 401; and Abrahams "The Contemporary Legal Environment" in Mills and Stremlau (eds) The Privatisation of security in Africa (SAllA, 1999) 81.

9 Leander 2005 33(3) Millennium-Journal of International Studies 810.

10 This is because they operate on the same principles except for their corporate mantle. See Singer 44; Percy Regulating the Private Security Industry (2006) 14; and Chesterman "Leashing the Dogs of War" 2005 5(1) Carnegie Reporter 37. 
"mercenaries" matters not at this time, because the PMSCs are here to stay. Moreover, if they were to be considered as mercenaries then the answer would lie in strengthening the enforcement processes in the anti-mercenary treaties, something that has its own problems. The focus, I believe, should be on creating rules that will ensure that PMSCs operate according to the principles of international law and not on configuring their status.

Secondly, new challenges to the perceptions of security, especially with regard to state power and monopoly of force, have become evident, thanks to globalization. Normative regimes designed solely on the basis of such monopoly decree reveal a glaring deficiency in the state's ability to deal with newer manifestations of threat to peace and security. In no place has such anomaly been apparent than in contemporary Africa where internal conflicts have exposed the limitations of state military structures and provided weak governments with the excuse to scamper for private military services offered by PMSCs. Unfortunately, PMSCs are mostly private contractors, hired by companies with government contracts, which means that the state has very little control on what they do. Also, PMSCs hire "third country nationals" who have little to do with the client state. Unlike state-controlled military, it is doubtful if the PMCs have a military command structure, or whether their personnel maintain a strict code of military conduct. The problem is compounded when PMSCs are hired by private companies, NGOs and intergovernmental agencies, all of which are not under the direct control of the host state, or contracting governments. But the overall question is: Why do states use PMSCs when their operations are so fraught with complexity? Why shouldn't governments simply improve their militaries or simply avoid settling their disputes through force? The answer from neo-liberalists would be that PMSCs are cheaper. Indeed, there has been suggestions that PMSC activity can be controlled adequately by the market forces and so there is no need for state-sponsored oversight regimes.

Thirdly, the willingness by some powerful countries, such as United States, to utilize the services of PMSCs without external oversight have diminished any appetite for developing an all-encompassing international regulatory framework. This, in my view, is the crux of the problem. While these entities have been at the centre of armed conflicts that developed countries have engaged in recently, they have remained largely insular to demands for greater transparency, democratic accountability and respect for human rights. ${ }^{11}$ In some cases, the developed nations, who are both clients and watchdogs of the industry, have abetted the lack of transparency and accountability of PMSCs to protect their own national interests. One analyst has noted that it is precisely because of lack of rules of oversight, or their underdevelopment that contractors are used. ${ }^{12}$ This also reflects the "power" that PMSCs now wield in the security sector. In the United States for example, PMSCs have become significant because of the manner in which they influence the security debate, even in the highest levels of government. Many

11 Richards and Smith "Addressing the Role of Private Security Companies Within the Security Sector Reform Programmes" 2007 5(1) Journal of Security Sector Management 1 http://www.ssronline.org/jofssm/issues/jofssm_0501_richards\&smith.pdf?CFID=1195345\&CFT OKEN=66356381 (accessed on 2009-05-20).

12 Leander 2005 33(3) Millennium-Journal of International Studies 820. 
key figures in government have interests in the PMSC industry, as was the case with Dick Cheney, the former US Vice-President, and the Halliburton Company. ${ }^{13}$ Some analysts have suggested that because of this relationship (where PMSCs and public authority become intertwined), PMSCs are able to persuade governments to use force as a foreign-policy instrument. ${ }^{14}$ And when governments do so, they are unlikely to allow for external scrutiny of what they do, or whom they associate with, because matters of security are of national interest. A case in point was the deliberate efforts by the Bush regime to defeat the rules against torture claiming that the war against terror was an extraordinary situation which called for an extraordinary response. ${ }^{15}$

\section{Should PMSCs be regulated at all?}

Why seek regulation of PMSCs when the political tide is obviously against it? The rise of neo-liberalism brought forth the ideas of rights and freedoms which have now acquired a peremptory status in international relations. Whether or not political climate favours certain activity, its viability still has to meet human-rights standards. But these apart, subsequent developments, especially after the collapse of communism, have put under strain the normative structure upon which international governance is founded. While relying on realist assumptions, these structures have been slow to devise norms that could respond adequately to the challenges wrought upon it by the changing international security landscape. Therefore, a vacuum has been created, the manifestations of which are the clear lack of accountability for human-rights violations and the persistent disregard for the rules of international humanitarian law by private security operatives. A few incidences that have come under the international spotlight which show the extent of the problem are the infamous sex-slavery ring operations organized by senior DynCorp managers in Bosnia in 2001; the human-rights abuses in Abhu Ghraib prison in Iraq, ${ }^{16}$ the incident involving Blackwater (re-named Xe) personnel who in September 2007 fired at a civilian car in the streets of Baghdad and killed all its occupants. ${ }^{17}$ In August 2009, Danny Fitzsimons, a British national and an employee of ArmorGroup, was arraigned before an

13 Dick Cheney was not the only one. Frank Carlucci, who was Secretary of Defence under Reagan, was the head of BDM when the firm began to get government contracts. BDM acquired control of Vinnell that got the bulk of training contracts in Iraq. Diligence LLC's Chairman, Joe Allbuch, was the campaign manager for President Bush. But the firm was founded by William Webster who at one time was at the helm of $\mathrm{FBI}$ and $\mathrm{CIA}$.

14 Leander 2005 33(3) Millennium-Journal of International Studies 808.

15 See the Supreme Court decision in Hamdan v Rumsfeld 548 US 557 (2006), where it was held that the prohibition against cruel inhuman and degrading treatment in Geneva Conventions was applicable in the war against Al Qaeda. This was against the Bush administration's assertion that it had the authority to establish military tribunal at Guantamo Bay.

16 See Amann "Abu Ghraib" 2005 153(6) University of Pennsylvania Law Review 2085.

17 See Raghavan and White "Blackwater Guards Fired at Fleeing Cars, Soldiers Say" 12 October 2007 Washington Post; Tavernise and Glanz "Iraq Report Says Blackwater Guards Fired First" 19 September 2007 New York Times; and Fainaru "Where Military Rules Don't Apply: Blackwater's Security Force in Iraq Given Wide latitude by State Department" 20 September 2007 Washington Post. 
Iraq court on a charge of murder of two of his fellow workers. ${ }^{18}$ Normative deficiency poses a major bottleneck to dealing with the human-rights problems associated with the operations of PMSCs and therefore dominates the greater breadth of the debate on the future of private military/security industry.

Apart from the foregoing, absence of a regulatory framework for PMSCs poses a risk to state security when renegade employees forge links with organized crime syndicates, bands of rebel soldiers who survive on ruthless and illegal extraction of natural resources. In situations of conflict, these entities could contribute to the prolonging of conflict and a greater hindrance to peace. These problems are aggravated by inchoate and sometimes minimal legislative mechanisms in their home countries. So although theoretically, PMSCs operatives may incur criminal and civil liability for violation of human rights and international humanitarian law, prosecutions are very rare. Even in the US where strings of regulatory frameworks do exist, there are gaps in the law which shield a substantial number of cases. In US $v$ Passaro ${ }^{19}$ for example, the suspect, who was a CIA contractor, was charged under the Patriot Act, US Code 18 section 7(a)(A) with 2 counts of assault with a dangerous weapon with intent to do bodily harm, and 2 counts of assault resulting in serious bodily injury against a detainee in Afghanistan. The detainee died two days after interrogations by the suspect. Ordinarily, the suspect should have been charged under the Military Extra Territorial Jurisdictions Act, but this Act only has jurisdiction over contractors employed by the Department of Defence. Also, the prosecutors elected to charge Passaro only with assault instead of murder or torture under domestic law, claiming that there was no evidence that would have supported such serious charges. The Patriot Act became only marginally applicable because the incident took place on land or facility designated for use by the US government. ${ }^{20}$ Passaro was convicted and sentenced to eight years and four months by a North Carolina court for the offence in February 2007. On appeal to the US Court of Appeal for the $4^{\text {th }}$ Circuit, the conviction was affirmed. ${ }^{21}$ Unfortunately, there are many cases of a similar nature that go unpunished because they escape media attention.

18 BBC, UK Worker held in Iraq Death, 9 August 2009 http://news.bbc.co.uk/2/hi/uk_news/ 8192285.stm (accessed on 2009-09-10). This resulted in the passing of the Military Commissions Act of 2006.

19 United States $v$ Passaro No 5:04-CR-211 BO (E.D.N.C. Oct 26, 2006). See also Bailey "United States v Passaro: Exercising Extraterritorial Jurisdiction over Non-defence Department Government Contractors Committing Crimes Overseas under Special Maritime and Territorial Jurisdiction of the United States" 200958 Catholic University Law Review 1143.

20 Laws prohibiting torture and inhuman treatment of detainees are elaborate in both international and domestic legal systems. Article 75 of the $1^{\text {st }}$ protocol to the Geneva Conventions 1977 forbids "violence to the health or physical or mental well-being" of detainees. The Torture Convention which forbids torture (defined as the inflicting of "severe pain or suffering, whether physical or mental" for purposes including obtaining information) as well as "cruel, inhuman and degrading treatment or punishment". There are various laws within the US legal system that equally forbid such inhuman and degrading treatment. For example, the US Uniform Code of Military Justice (which covers members of the armed forces) and the criminal code (for CIA agents and private contractors) provide for offences related to assault, manslaughter and murder. (Article 118 of the UCMJ forbids murder; Article 119 forbids manslaughter; and Article 128 forbids assault).

21 No 07-4249 (Decided 10 August 2009). The court, however, vacated the sentence and remitted the matter back to the trial court. 


\section{Charting an African course}

In Africa, the effect of privatization has been felt far and wide. Infused through multilateral donor institutions such as the World Bank and the IMF and their demand for the restriction on governmental spending and downsizing of the public sector, the security industry has been forced to succumb to lesser governmental control and support. But, the growth of the industry has also been linked to the visible presence of "international corporate activities and development personnel and their awareness of risk and insecurity". ${ }^{22}$ Globalization has now made it possible to seek openly private alternatives in areas that were hitherto "not only prohibited, but unthinkable". ${ }^{23}$ But, as aforementioned, globalization has rendered more constraints than benefits to African states. While it has contributed to the integration of the greater part of the global economy, it has resulted in the marginalization of Africa and its peoples. ${ }^{24}$ The undersides of globalization were compounded in the earlier years, by the infamous structural adjustment that weakened public institutions and made them less responsive to security needs of citizens. ${ }^{25}$ Today, such trends undermine democracy and the establishment of the rule of law when bureaucratic and corrupt political leaders seek assistance of PMSCs to sustain their hold on power. ${ }^{26}$

Given such complexities, the discourse on privatization of security in Africa must be broadened to canvass issues such as the shifting structures of security, transformation of governance and authority at the local and international level, contestation over political community, issues of state capacity, and the magnification of the role of transnational networks. These issues indicate a broader debate than just the design of black-letter law on what PMSCs should or should not do, or who should have responsibility for what PMSCs do. It is suggested here that seeking to regulate PMSCs offers an opportunity for putting in place wide-ranging normative frameworks that might bolster Africa's ability to improve its security situation. It also provides an opportunity for redressing some of the problems created by globalization. But the process needs to be holistic and all-encompassing because individual African governments cannot be trusted. This is why it is suggested that the process of norm formulation should begin at the continental level before it cascades down to individual countries. For Africa to have a voice, it must present a common front that will not only restrain the undersides of privatization and minimize the undesirable consequences of globalization, but also stimulate growth in other areas of human endeavour. The collective

22 Abrahamsen and Williams "Introduction: The Privatisation and Globalisation of Security in Africa" 2007 21(2) International Relations 131138.

23 Thomson Mercenaries, Pirates and Sovereigns: State Building and Extra-Territorial Violence in Early Modern Europe (1994) 145.

${ }^{24}$ Gibb "Globalisation and African Economic Recovery: Compatibility or Contradiction" in Gibb, Hughes, Mills and Vaahtoranta (eds) Globalisation, African Recovery and the New African Initiatives (2002) 9.

25 See generally, Hills Policing Africa: Internal Security and the Limits of Liberalisation (2000).

26 Apart from situations of active conflict, there are instances when tottering regimes have hired mercenaries to bolster their security. A recent example is that of DR Congo where the late Laurent Kabila used mercenaries from South African mercenary outfits. See "South African Mercenaries in Congo" 28 August 1998 Mail \& Guardian http://ospiti.peacelink.it/ bukavu/rs/CON4_43.html) (accessed on 2010-01-20). 
approach is what brought about independence for a majority of people in the continent, and it is what will free the same majority from of the exploits of profit-minded security operatives.

\section{OVERVIEW OF THE EXISTING FRAMEWORKS}

\section{The UN Working Group process}

Up until the 1980s, there was little effort at the UN level to move away from the narrow focus on "mercenaries" that had characterized normative approaches to privatized security in the last the century. The approach, which was primarily "prohibitionist" in nature, was evident in the string of UN treaties and regional normative responses to what was perennially perceived as the mercenary threat. But, things began to change somewhat, especially in the latter half of that decade. Inspired by what was then perceived as the reemergence of the "mercenary" or the "new mercenary", the UN appointed a Special Rapporteur on the Use of Mercenaries as a Means of Violating Human Rights and Impeding the Exercise of Rights to of Peoples to Selfdetermination in 1987, to investigate the status of the phenomenon and maybe provide insights on how to deal with it. ${ }^{27}$ Although crafted on a prohibitionist template, the mandate of the Special Rapporteurs was more or less open-ended, allowing them to solicit information, not only relating to human-rights violations but also on the status of the industry in general. One thing that became evident from the reports filed by Enrique Ballesteros, the first UN Special Rapporteur, was that the private-security industry was growing steadily and gaining much more acceptance from governments. ${ }^{28}$ Indeed, before the end of the 1990s, there was already a discernable change in the conceptualization of security, which in turn, was fuelling the need to reconfigure international response to private security beyond the narrow focus on mercenaries. Thus, for the UN to remain relevant, it had to begin drawing a distinction, albeit nominally, between the illegal mercenary and the newer legitimate corporate security enterprises. When the UN Mercenary Convention finally came into force in 2001 , this realization had already taken root, thus leaving unattended the issue of PMSC of regulation. Yet, despite this glaring need, the UN still pushed for wider ratification of the Convention as if it were to be the panacea for the PMSC problematique.

Subsequent to the Convention, the UN became proactive in dealing with the manifestations of the private-security industry that were in violation of the treaty, but leaving the acceptable ones, or the so-called "good guys", to their own devices. In the UN approach, the regulation of PMSCs was merely a factor of dealing with a greater threat of "mercenaries" and not an undertaking deserving of attention on its own right. For example, in December 2004, the UN General Assembly acknowledged that "newer forms of mercenary activities" were evident and asked the Special Rapporteur and the Office of

27 Prado "Private Military and Security Companies and the UN Working Group on the Use of Mercenaries" 2009 13(3) Journal of Conflict \& Security Law 429.

28 Zarate "The Emergence of the New Dog of War: Private International Security Companies, International Law and the New World Order" 199834 Stanford Journal of International Law 34. 
the High Commissioner on Human Rights to pay special attention to these. ${ }^{29}$ In reference to the PMCs, the Assembly only requested that an assessment be made on the impact of the activities of "private companies offering military assistance, consultancy and security services on the international market" on the exercise of people's right to self-determination. Nonetheless, the UN approach towards regulating PMSCs is still cautious, maybe because of the lingering suspicion of the linkage that might exist between PMSCs and mercenaries. This is evident from the way in which UN has responded to the PMSC issues. For example, when the office of the Special Rapporteur was replaced by the Working Group on the Use of Mercenaries as a Means of Violating Human Rights and Impeding the Exercise of the Right of Peoples to Self-determination ${ }^{30}$ in 2005, the word "mercenaries" was not dropped from its name despite the Working group becoming the centre of all UN activity on PMSC related matters.

The foregoing notwithstanding, there has been some activity in UN circles that suggest a more active engagement with PMSCs in the future. In 2004, the Office of the High Commissioner for Human rights convened a third meeting of experts to assess the role of the newer forms of mercenary activities and how they affect human rights. The report of the experts made three recommendations in relation to the regulation and supervision of these companies: to set thresholds for permissible activity, systems of registration and oversight mechanisms; to develop codes of conduct for these companies, and to devise structures for international supervision that could provide oversight on legislation, provide a centre for collating and information and overseeing contracts between companies and contracting states on the basis of human-rights standards. ${ }^{31}$ Among the activities which the companies should be prohibited from performing are armed conflicts, creating private armies, illicit trafficking of arms, recruiting mercenaries and being involved in illegal extraction of natural resources. Notably, the report encouraged the use of PMSCs by governments "to improve the efficiency and responsiveness of the military", on condition that there was "transparency, accountability and regulation". 32 The UN General Assembly noted this report in 2006 and enjoined states to exercise vigilance against any recruitment by PMSCs of mercenaries and impose ban against any activity by these companies that may destabilize constitutional regimes. ${ }^{33}$ In 2008, the UN made a more direct assertion of the need for regulation of the PMC activity. In resolution 62/145, the Assembly called on member states to ban any companies that intervene in armed conflicts or engage in any activity that might destabilize constitutional regimes. It also encouraged states that engage the services of

29 See UN General Assembly Resolution 59/178 http://daccessdds.un.org/doc/UNDOC/GEN/ N04/486/94/PDF/N0448694.pdf?OpenElement) (accessed on 2009-05-30).

30 Hereinafter "the Working Group".

31 The third expert meeting was held in Geneva between 6-10 December, 2004. For the text, see E/CN.4/2005/23 http://daccessdds.un.org/doc/UNDOC/GEN/G05/103/64/PDF/G0510 364.pdf?OpenElement) (accessed on 2009-05-30).

32 See fn 31 above, par 30 . This was in the context of the African conflicts where some PMCs had assisted local and international forces in DDR programmes and the "demining" of certain regions. It should be noted nevertheless that even within the expert group there was discomfort on recognizing as legitimate the role of PMCs. See par 97 of the Report.

33 UN General Assembly Resolution 61/151 http://daccessdds.un.org/doc/UNDOC/GEN/N06/ 503/49/PDF/N0650349.pdf?OpenElement) (accessed on 2009-05-30). 
PMSCs to, "establish regulatory national mechanisms for their registering and licensing of those companies in order to ensure that imported services provided by those companies neither impede the enjoyment of human rights nor violate human rights in the recipient country".

The work being done by the UN Working Group (WG) is becoming significantly much more geared towards assessing the need for a regulatory framework for PMSCs independent form the UN Mercenary Convention. Created in response to resolution 2005/2 of the UN Commission on Human Rights, the Working Group (WG) is now composed of five independent experts drawn from the 5 geopolitical regions and who serve for a period of three years. Its mandate, which include norm creation, monitoring of mercenary or mercenary-related activity, seeking government and nongovernment organizations' opinions on issues related to its mandate, and monitoring human rights violations by private security/military companies, reflects the attitude within the UN circles towards PMSCs. Initially, WG focus was on mercenaries but this has changed. Currently, the WG has produced the Draft Convention on the Regulation, Oversight and Monitoring of Military and Security Companies ${ }^{34}$ and is actively seeking its approval by all major stakeholders. ${ }^{35}$

\section{2 "Home" and "contracting" state-based mechanisms}

A number of scholars have suggested that one way through which activities of the PMSCs could be regulated is through a licensing procedure. Obviously this entails the more difficult task of linking PMSCs to states so that their activities can be "attached to state responsibility". ${ }^{36}$ A number of states, including United States, United Kingdom, Australia, Israel and South Africa have adopted this strategy by enacting domestic legislation. Both the USA and the South African legislations created a licensing process which gives the state the powers of control in the conduct of business. However, they do not detail the nature of responsibility that the state will take and how business ought to be carried out. The South African legislation does not link the issuance of license to an undertaking for the observance of international norms.

Generally, the state-based regulatory frameworks suffer serious limitations in curbing excessive activities of multinational corporations. In the first place, states face a great challenge in applying public norms to private business relationships. Secondly, these companies have offshore activities that

${ }^{34}$ Draft Convention on the Regulation, Oversight and Monitoring of Military and Security Companies 13 July 2009 http://www.mgimo.ru/fi les/121626/draft.pdf (accessed on 2009-0520). For a recent commentary on the Draft Convention see Gumedze "Addressing the Use of Private Security and Military Companies at the International Level" November 2009 ISS Paper 206 http://search.sabinet.co.za/WebZ/Authorize?sessionid=0\&bad=ejour/ejour_bad search.html\&portal=ejournal\&next=images/ejour/ispaper/ispaper_n206.pdf) (accessed ${ }^{-}$on 2010-05-20).

$35 \mathrm{Eg}$, the Working Groups held its first consultative meeting in African soil in Addis Ababa on 3 and 4 March 2010. See Press release OHCHR "UN and Africa to Discuss Mercenaries and Private Military/Security Companies" 25 February 2010 http://www.ohchr.org/en/ NewsEvents/Pages/DisplayNews.aspx?NewsID=9844\&LangID=E (accessed on 2010-05-15).

36 See eg. Desai "Have Your Cake and Eat It Too: A Proposal for a Layered Approach to Regulating Private Military Companies" 200539 University of San Francisco Law Review 854. 
technically fall outside the jurisdiction of national legal systems. PMSCs operations often spread across borders, in terms of contracts performance, organizational base, and even recruiting of personnel. Although a company may be based in US, its main work may be in Iraq with personnel drawn from all over the world. This suggests that monitoring or oversight authorities should not only have extraterritorial jurisdiction, but be capable of collecting evidence from activities that may not be within their borders. Poorer states, such as those in Africa, are unlikely to enforce any regulatory measures that require extensive resources. As for states in which PMSCs operate, they are usually those experiencing some form of strife or just coming out of one. Countries such as Iraq, DR Congo, Afghanistan and even Somali, are wracked by insecurity and cannot have strong enforcement mechanisms. These reasons perhaps explain why not many poorer nations are enacting any legislation meant to regulate PMSCs resident or carrying on business in their territories.

\section{3 "Market-based" and "self-regulatory" mechanisms}

The key to corporate survival, one analyst has said, "resides increasingly in a political or even cultural capacity; the ability to influence future customers and suppliers". ${ }^{37}$ Thus, the market-based regulatory framework presuppose that clients of PMSCs will only hire firms that respect human rights and have a history of compliance with international humanitarian law. Therefore, PMSCs will seek to be internationally "acceptable" to gain contracts from reputable clients such as the UN and the International Committee of the Red Cross. Unfortunately, these organizations are not the only consumers of private security services. It is a well-known fact that those who employ PMSCs include states and non-state actors. These groups may not have a similar view on what constitutes acceptable behaviour or be legitimate firms. PMSCs on their part claim that they have an interest in sustaining good relations with governments. Therefore, they strive to conduct their business in a manner that does not bring disrepute to their clients. Since they are primarily business entities, they have a responsibility to retain personnel by not engaging in unnecessarily risky and illegal activities; endeavouring to bid for long-term contracts with governments which can only come if they maintain good reputation and deliver the service. Thus they have little incentive to violate human rights or destabilize governments. PMSCs argue that just like governments, they have interests in ensuring peace and stability in areas where they operate. An official of Executive Outcomes, a defunct security company that was based in South Africa, once declared his company's commitment to the strengthening of self-determination of the peoples of Africa. ${ }^{38}$ While advocating for more involvement of PMSCs in Darfur and other conflict zones in Africa, Doug Brooks, the President of IPOA has asserted that:

37 Lovering "Loose Cannons: Creating the Arms Industry of the Twenty First Century" in Kaldor (ed) Global Insecurity (2000) 147, 167.

38 See Report on the Question of the Use of mercenaries as a means of Violating Human Rights and Impeding the Exercise of Right of Peoples to Self-Determination, submitted by Enrique Bernales Ballesteros, Special Rapporteur, pursuant to Commission Resolution 1995/5 and commission Decision 1996/113, UN ESCOR, 53d Sess., Agenda Item 7, 89, UN Doc. E/CN.4/1997/24 (1997). 
"Private security companies have some of the greatest potential to provide desperately needed humanitarian security services in support of $A U$ and UN peacekeepers. By directly protecting at-risk populations, they could allow the international military forces to focus on enforcing their mandate ... The private sector offers realistic and less expensive answers to many dilemmas facing peace operations and empowers policy makers with new tools and more effective peacekeepers."

But the role of PMSCs in the broader security debate envisions a much more complex understanding of the shift from "state to market" and the implications thereof to governance. ${ }^{40}$ When profit-oriented companies take on the role of alternative suppliers of security to citizens and state, this infers the "commodification" of security. The effect, according to Krahmann, is the increase in the supply of security to individuals and the decrease in the provision of national and international security; the increase in the promotion of values consistent with the individualism, as opposed to the "collective good" promoted by states; the magnification of threats and increase of security costs; and the over-emphasis on protection rather than prevention. ${ }^{41}$ It seems, therefore, that the market forces provide inappropriate tools for regulation, because they lead towards more privatization to meet the market demands. They also don't ensure the achievement of the long-term goals of a security regime. It addresses the threat without bothering with the causes, and thus sustains itself by the reproduction of the situations of anxiety and fear. Leander argues that the "mobilization of insecurity and fear" which is in itself self-regulating, is linked to a phenomenon she calls "neo-liberal governmentality"; a situation where marketing security generates its own demands. ${ }^{42}$ No wonder PMSCs are now involved in identifying security threats and evaluating the different policy options. ${ }^{43}$

The rationale for self-regulation of PMCs is similar to that of other business entities. Obviously, PMSCs have interest in keeping state-directed regulatory and oversight schemes at a minimum. Some industry players have long recognized that their continued survival may hinge on improving their image. Thus they have sought to establish internal mechanisms for accountability. Invariably, the industry has recognized that the bad publicity they have got in Iraq, Afghanistan and Africa is not entirely without cause. In response, the industry has now developed a full array of internal management systems and controls through cooperation. For example, industry players who are members of the British Association of private Security Companies (BAPSC), International Peace Operations (IPOA), Private Security Company Association of Iraq (PSCAI) and the newly-formed Pan African Security Association (PASA), have developed systems of controls and some even Codes of Conduct which bind them. IPOA for example, which has a membership of over 40 companies, has a Code of Conduct that sets out the members' responsibility on human rights, transparency, arms, safety and work

\footnotetext{
39 Brooks "Focusing on Sudan" 2006 2(1) Journal of International Peace Operations 4.

40 See generally, Avant (2005).

41 Krahmann 2008 14(3) European Journal of International Relations 389.

42 Leander 2005 33(3) Millennium-Journal of International Studies 810.

43 Spinner "Army May Allow Bids for Some KBR Work" 19 March 2004 Washington Post.
} 
place relations. ${ }^{44}$ The organization has a Standards Committee which is tasked with investigating any alleged infractions to the Code. However, the most stringent measure that the Committee may take against a member is to recommend expulsion. Considering the gravity of some of the human rights violations that have been committed by some of these companies such a measure is laughable. Moreover, such Codes cannot override the obligations created by international human-rights law and international Humanitarian law. ${ }^{45}$ The BAPSC on the other hand, requires that its members provide service with "high professional skills and expertise whilst recognizing that the countries where they are operating have inadequate frameworks." ${ }^{16}$ The organization is heavy on the promotion of good relations between its members and the government of UK and international bodies; compliance with values, interests and laws of the countries where they operate. Members of the association also affirm their acceptance of the self-regulating scheme set up by the association; to provide high-quality training to their personnel; to provide security and desist from engaging in armed exchange; endeavour to respect human rights including refusal to provide arms or services in situations where human rights are likely to be violated; refuse to provide to provide services in circumstances where their involvement might adversely affect the military or political balance in the client state.

Apart from the mechanisms housed within the various associations, an international self-regulatory regime has now been established in the form of International Code of Conduct for Private Security Service Providers which was opened for signature on 9 November 2010. ${ }^{47}$ The Code is a recent innovation by private security firms in association with the Swiss and United Kingdom governments to supplement the Montreux and other frameworks. It is not a binding document and observance is voluntary and mostly dependent on the relationship between contracting entities and the companies. It states in the preamble that its purpose is to "set forth a commonly-agreed set of principles for PSCs and to establish a foundation to translate these principles into related standards as well as governance and oversight mechanisms". The Code does not mention the word "military" and does not explicitly prohibit its signatories from engaging in military activities. A thinly-veiled reference to such activity can be read in principle 63, where companies are required to report on any incidents involving the use of firearms, or any escalation of the use of force, to their clients. Most of the code reiterates the common prohibitions against torture, slavery, sexual abuses and violations of international humanitarian law and introduces nothing new.

${ }^{44}$ Messner "Working Towards Effective Legislative and Regulatory Solutions for the Private Security Industry in Africa" in Gumedze (ed) Elimination of Mercenarism in Africa: A Need for a New Continental Approach (2008) 145, 166.

45 Gillard "Business Goes to War: Private Military/Security Companies and International Humanitarian Law" 2006 88(863) International Review of the Red Cross 525, 548.

46 See The BAPSC Charter http://www.org.uk/key_documents-charter.asp (accessed on 200809-24). One of the key objectives of the association is stated to be that of providing guidance on the substance of the need comply with "international legal statutes". Obviously, with limited regulatory regimes at the international level, the association is aware that its members may be best served by the self-regulatory framework.

47 http://www.dcaf.ch/privatisation-security/_index.cfm (accessed on 2010-11-12). 


\section{The Montreux Document}

In 2008, a number of states endorsed the Montreux Document on Pertinent International Legal Obligations and good Practices for States Related to Operations of private Military and Security Companies During Armed conflicts. ${ }^{48}$ The document is a culmination of efforts by the Swiss government and the International Committee of the Red Cross to create a regime for the regulation of PMSCs participating in situations of conflict. It is not a binding instrument but a mere statement of recommendations geared towards enhancing the states' control over PMSCs. From an ideological standpoint, the document is a major triumph for PMSCs because it has for the first time signalled the international community's acceptance of private security operatives in the context of an armed conflict. In this regard, PMSC organizations have been quick to welcome it and asserting that the document will form the basis for developing an industry-wide code of conduct that will have a wider application than the existing self-regulatory mechanisms. ${ }^{49}$ The document has two parts. The first part contains 27 obligations that states have to assume in regards to their regulation of PMSCs. These obligations are derived from the existing international instruments and the general principles of customary international law, and span the fields of international humanitarian law, mercenary law, human-rights law, and international criminal law. For purposes of delineating these responsibilities, the states arranged according to the categories listed in the document (into four): the "contracting states" (countries who hire PMSCs), "territorial states" (countries on whose territory PMSCs operate), "home states" (countries in which PMSCs are based) and "all other states". These obligations generally require that states ensure PMSCs' compliance with international law. They are to do this by enacting appropriate legislation that is in conformity with international instruments; ensuring methods of enforcement of the obligations created by such law, including investigating and prosecuting offenders; ensuring respect of international law; and taking responsibility of the activity of the PMSC which they contract, including the readiness to provide reparations whenever necessary, to parties who suffer as a result of PMSC activity.

The second part contains what is referred to as "good practices". Like the obligations aforementioned, these recommendations are meant to "provide guidance and assistance to states in ensuring respect for international humanitarian law and human-rights law" and to promote responsible conduct in states' relationship with PMCs operating in their territories. This part draws from existing practices and international instruments and contains 73 rules. These rules set procedures and criteria for the selection of PMSCs; basic terms of contracts; the criteria and procedure of authorizations to provide military and security services; terms of such authorizations; rules for provision

48 This document was produced by a joint effort of seventeen countries: Afghanistan, Angola, Australia, Austria, Canada, China, France, Germany, Iraq, Poland, Sierra Leone, South Africa, Sweden, Switzerland, the United Kingdom, Ukraine, and the United States of America. Also, PMSC industry and the NGO community were represented. The text http://www.un.org/ga/search/view_doc.asp?symbol=A/63/467 (accessed on 2009-05-23). See also, Cockayne 2009 13(3) Journal of Conflict \& Security Law 401.

49 Stürchler "The Swiss Initiative Comes Alive" 2008 4(3) Journal of International Peace Operations 910. 
of services; and procedures for monitoring compliance and ensuring accountability.

The document has some implications for the development of law in relation to the regulation of PMSCs. In first instance, it moves us away from the prevailing confusion with regard to the status of PMSCs under international humanitarian law. PMSCs are now obligated, "regardless of their status, to comply with applicable international humanitarian law". Also, PMSC operatives are generally considered to be civilians as provided for in Geneva conventions. PMSCs are also not authorized to use force. There are three notable exceptions, which in my view make this rule rather fluid. There is the notion of self-defence, which mirrors article 51 of the UN Charter, where force is applied in defence of another person "as determined by the law of territorial state"; and in cases where the PMSC has been incorporated into the regular army. Secondly, PMSC personnel are subject to the law of the territorial state. This means that no matter their nationality, the employees are expected to obey the full range of domestic laws of the country where they are working. This does not change much of the existing position only that it has implications if read together with other rules in the document, such as the requirement for corporation among states in their investigation, extradition and surrender of persons suspected of having committed crimes under international law.

In all these, the prime responsibility rests with states. As far as contracting states are concerned, their responsibility for violation of humanitarian or human-rights law by PMSC will arise where the PMSC is incorporated in the regular armed force; where are under the command of the state; if empowered to exercise elements of governmental authority, or to perform functions "normally" conducted by organs of state; and where the PMSC is acting under the instructions of the state. ${ }^{50}$ This borrows from the international law of state responsibility outlined in the Draft Articles on Responsibility of States for Wrongful Acts. ${ }^{51}$ The implication of this responsibility as far as PMSCs are concerned is that it might be possible to outsource services, but states will not outsource responsibilities. ${ }^{52}$ There is a problem with states having so much responsibility. It should be noted, however, that state responsibility is a doctrine that is rarely invoked. Perhaps this will change in light of the activities of PMSCs and the development of law in this area! Also, states with weaker legislations or those who delay in enacting appropriate laws will not be able to participate fully in the framework created by the document. The result will be that PMSCs will move to such states to avoid strict oversight. As we have indicated, states may have interest in shielding PMSCs which perform sensitive functions from public oversight. They may therefore enact laws that give immunity or restrict disclosure of information to the public. Considering state practices of the recent years, states do take responsibility for all the negative activities of the PMSCs just as much as the PMSCs themselves. Leaving regulatory functions entirely in their hands may

50 Para 7 of Part 1 of the Document spells out this obligation in rather elaborate terms.

51 See International Law Commission, Draft Articles on Responsibility of States for International Wrongful Acts, adopted at $53^{\text {rd }}$ Sess. November 2001, articles 5, 8 and 9. See also, Military and Paramilitary Activities in and Against Nicaragua for the "effective control test" under international law.

52 See Stürchler 20084 (3) Journal of International Peace Operations 12. 
not solve much of the problems with the PMSC industry. In this regard, the document should have given some recognition to the civil society, especially in the monitoring of accountability of PMSCs in conflict situations.

\section{IMPERATIVES FOR CREATING VIABLE REGULATORY FRAMEWORKS}

To what extent is the existing approach to regulation of PMCs capable of improving effectiveness and efficiency in the wider security sector? The question which a regulatory framework should answer is no longer whether private military/security entities should be allowed, but how they should operate alongside state institutions so as to provide effective and accountable security for the entire population in conditions of peace, and render a positive contribution towards efforts to manage conflicts and promote sustainable peace. Some groups have therefore called for "a global framework" to identify, implement and enforce relevant standards across the industry, assisting states to achieve affective regulation which has both preventive and remedial functions. This approach would ensure that the industry operation is in conformity with international legal norms and at the same time provide measures for ensuring accountability. In my view, global approach is likely to be undermined by exigencies of politics as mentioned. Therefore, I suggest imperatives that could guide a regional approach, preferably at the continental level.

Four key imperatives for developing a viable international regulatory framework at the continental level are discussed here. The first is assisting states to discharge their legal duty to protect human rights. There is absolutely no doubt that states should be able to control the use of force within their territory. This is consistent with the responsibility that they have towards their citizens and the order to which they are called as members of the international community. The current web of international instruments and international customary law prescribes rules on the use of force that bind states. In addition, states are also signatories to various human-rights instruments, some of which contain rules of a peremptory nature, and which invite individuals to make complaints directly to regional and international bodies if they suffer as a result of any violation. It is imperative therefore that states should be able to regulate the activities of PMSCs operating within their territories or from their territories, especially since such operations carry risks to the individual citizens and the state as well. Part of the reason why regulating PMSCs have proved difficult for states is because existing international and regional instruments provide limited avenues of enforcement. Also, the global nature of the PMSCs operation demands that states act in concert to enforce international standards. This has not been possible because of the vagaries and inconsistency of international politics, aggravated by the dichotomy of opinion on who really is a "mercenary". Drawing the lines of responsibility and creating an understanding on the functions that can be allowed and those which remain as the "core functions" of the state are definitely important.

The second imperative involves the need to clarify the status and appropriate functions of the PMSCs. Obviously, the contracting states should 
be able to determine whether involving PMCs in direct hostilities is much more helpful and cost-efficient than keeping them out of combat. Alternatively, states may consider incorporating PMSCs into their militaries. The question on the status of PMC is unlikely to go away given the nature of African conflicts that we see today. Invariably, the internal armed conflicts involve civilians either as targets or participants in guerrilla forms of combat. In these situations PMCs' operatives become targets just as much as combat soldiers. What is the responsibility of PMSCs and what status do they enjoy in such circumstances? Paragraphs 26 and 27 of the Montreux Document which sought to address this imperative reveal some gaps. In paragraph 26, PMSC personnel enjoy both civilian and hors de combat protections under IHL. This ambiguity of status is maintained depending on the functions that the PMSC is engaged in. Instead of clarifying the circumstances in which superiors may be held responsible for the conduct of their subordinates, it merely provides that the question will determined in "accordance with the rules of international law".

The third, imperative for designing a continental regulatory framework for PMSCs, is to encourage stakeholders' involvement in security policy making what some might regard as the harnessing of the "epistemic power" towards security regulation. It cannot be disputed that PMSCs interact with all sectors of society and their influence in public administration, policy formulation and the military may have a profound effect in the manner in which the security industry is managed. In the recent past an increased presence of PMSCs as lobbyists, trainers and consultants has cut across the public/private sector divide. An emerging shift towards the de-politicization of security and moving it out of the public realm are now evident. According to Leander, this development has disempowered the "civil component of the state and the civil society advocates of non-military security approaches". ${ }^{4}$ Yet, alienating the civil polities from the security debate may not augur well for the future stability of society. Traditionally, the civil society and especially the NGOs have been quite instrumental in monitoring abuses of human rights by transnational entities and governments. Also, they have been pivotal in the development of international normative regimes. In this regard, creating a role for the civil society lessens the burden on states, as far as monitoring of PMSCs is concerned. The UN Working Group process could benefit from this endeavour as well. In the Montreux Document, the PMSCs and governments played a larger role than the international civil society. This is because of the suspicion that exists between PMSCs and NGOs as the latter often push for stricter observance of human rights standards. Nonetheless, the whole idea of bringing NGOs on board is to harness all the perspectives and strive for improvement of PMSCs' performance on all scores. Moreover, MMSCs' getting the civil society involved may validate further PMSC activity in the continent.

53 In par 26, the question of "superior responsibility is avoided under a blanket referral to the rules of international law". This is contrary to the spirit of Geneva Conventions - either you are a civilian and Fourth Geneva Convention applies, or you are a combatant, and the Third Geneva Convention applies. See generally, Pictet Humanitarian Law and the Protection of War Victims (1975).

54 Leander 2005 33(3) Millennium-Journal of International Studies 810. 
Lastly, is the whole idea of improving PMSCs' accountability to clients and other stakeholders, which has become key to the future of PMSCs' operation. Undoubtedly, relying on "market forces" and "internal self-regulation", have so far failed to provide useful check to the activities of the PMSCs. Establishing accountability regimes may also protect the contracting states as well. There are cases where PMCs have simply abandoned their work, or their personnel have simply fled from the scene when the mission becomes dangerous. A clear sense of responsibility articulated in a regulatory regime can protect both parties - by ensuring that PMCs personnel are not assigned dangerous combat duties, and the state has recourse when the contracts are not performed in accordance with the agreement. Thus a key imperative in PMC regulation ought to be the clarifying and improving contract management. In Africa the imperative is crucial especially in cases where the contracting states may be lacking in resources to pursue such companies abroad. Matters may become even more complicated in situations where the operations are carried out in a country with no government and the contracting entity and the PMSC are from abroad.

\section{CONCLUSION}

Security is now a major issue that stands between many countries in Africa and their desire to move away from conflicts and build peace. It also affects their ability to implement human-rights protection programmes, and improve their economic performance. In many continental discourses, security and development are juxtaposed. In the NEPAD framework, for example, lack of security is identified as a major hindrance to continental development. One way in which states have responded to the conundrum is to seek private security arrangements. Indeed, as widely reported in the media, these states, including the African Union (AU), have used private security companies whenever they find it expedient to do so. Thus, the question of regulating such entities hinges on an experience that is not entirely alien to Africa. Moreover, many of these companies now see Africa as the potential market for their services and are vigorously marketing their services around the continent. ${ }^{55}$ These factors indicate the necessity of Africa immersing itself in the debate and providing the driving force for the development and the establishment of rules, procedures, and institutions that will determine the future of private security/military operations on the continent. Considering too, the fragility of Africa's political landscape, the negligible pace at which peace-building and post-conflict reconstruction programmes are implemented, and the prevalence of insecurity, this debate is necessary and urgent.

Given the imperatives discussed above, it is impossible to envision a single regime as capable of regulating all aspects of the private security industry. Neither can it be possible to have regulations operate at single level of polity. As far as Africa is concerned, it has been proposed that the best way to go at this moment is to draw a non-binding set of regulations contained in what could be referred to "Guidelines for the Operation and Monitoring of

55 Gumedze "Pouring Old Wine into New Bottles? The Denote around Mercenaries and Private Military and Security Companies" in Gumedze (ed) Elimination of Mercenarism in Africa: A need for a New Continental Approach (2008) 21. 
PMSCs" ${ }^{56}$ These guidelines could outline in broad terms the security aspirations of the peoples of the continent, the nature and form which PMSCs' involvement in conflict and other situations should take, the responsibility of states, role of NGOs and enforcement mechanisms. These Guidelines could then provide outlines for PMSC regulations in individual countries. The Guidelines should be developed as a matter of urgency so that countries do not feel inhibited from engaging the services of PMSCs and at the same time, ensuring transparency in the industry. Secondly, the Guidelines will outline continental standards that would probably be useful in designing domestic and international regimes. Thirdly, they will provide a united response to the current efforts at developing an international convention. There are various instruments from which such Guidelines could be drawn so that they meet the imperatives of regulation discussed above. ${ }^{57}$ These instruments are of softlaw character and therefore do not create an enforcement regime. Invariably, they rely on states to take a greater role in enforcing some of these measures.

Like all in all other cases, the most effective enforcement strategy for a regulatory framework will always be the state. But in the African context, things often get very complicated, especially in areas of conflict or civil strife. In such situations, the state machinery may have collapsed or its effectiveness compromised by paucity of resources and corruption. Indeed, in a majority of such situations the very legitimacy of government, let alone its claim to the use of force, is questioned. In such cases, the responsibility for security must necessarily shift to regional and international organizations. Moreover, PMSCs that operate in such spaces are either contracted by external agencies or are aligned to groups that have access to natural resources and hence connected to the global trade networks. Achieving effective regulation of the PMSCs must therefore depend on a supra-national regime that sets normative standards and decrees best practised for PMSCs in line with what has been suggested.

56 Juma "Mercenarism: Looking Beyond the Current International and Regional Normative Regimes" in Gumedze (ed) Elimination of Mercenarism in Africa: A need for a New Continental Approach (2008) 197.

57 Some of these are: the UN Code of Conduct for Law Enforcement Officials (GA Res.34/169, 17 Dec., 1979) Voluntary Principles of Security and Human Rights http://www.state.gov/g/ $\mathrm{dr} / \mathrm{rls} / 2931$.htm) (accessed on 2009-06-20); UN General Compact, UN Basic principles on the Use of Firearms by Law Enforcement Officials http://www.unglobalcompact.org (accessed on 2009-06-20); The Basic Principles for the Treatment of Prisoners http://www.ubhchr.ch/html/ menu3/b/h comp43.htm (accessed on 2009-06-20); the Standard Minimum Rules for the Treatment of Prisoners (GA Res 45/111, 14 Dec., 1990); the Tripartite Declaration of Principles Concerning Multinational Enterprises and Social Policy http://www.ilo.org/public/ english/employment/multi/download/english.pdf (accessed on 2010-06-20); Norms and Responsibilities for Transnational Corporations and Other Business Enterprises with Regards to Human Rights (UN Doc.E/CN.4/Sub.2 /2003/12/Rev.2); and The Montreux Document, and the SEESAC Sarajevo Code of Conduct for Private Security Companies http://www.seesac.org/reports/Code\%20of\%20 conduct.pdf) (accessed on 2010-06-20). 